DOI: $10.1515 / \mathrm{abcsj}-2017-0012$

\title{
The Teaching Life as a House of Troubles
}

Alex Kudera, Auggie's Revenge (Orlando: Beating Windward, 2015. 249 pp. ISBN 9781940761244 )

Alex Kudera's recent novel, Auggie's Revenge, is set in the same academic limbo in which his earlier Fight for Your Long Day is set, and there are even links to its protagonist Cyrus Duffleman there, but the focus in some ways is very different, and oddly prescient of the recent American elections. Michael Vittinger, who does the majority of the narration and is the apparent protagonist of this novel, is an adjunct professor of philosophy - that is, a part-time non-tenure track universitylevel teacher - in one of the universities which Duffleman had commuted to and from in Long Day. In fact, Michael - known primarily, when referred to at all by other characters, as "Prof" - mentions that he used to share an office with Duffleman and a number of other adjuncts. In another instance, he mentions Duffleman's flatulence. Obviously, this social realm is in the literary historical mode that Northrop Frye called the Ironic, in which the characters, far from being Mythic-mode gods, Romance-mode supernatural beings, High Mimetic-mode royalty, or Low Mimetic-mode average people, are subhumans. Indeed, one is reminded of the "hemorrhoidal" clerk Akaky Akakievich from Gogol's short story "The Overcoat," or of the ambitionless Bartleby from Melville's short story "Bartleby the Scrivener." That is to say that Kudera's examination of the powerlessness of the contemporary academic underclass in American universities has deep roots in literary realism.

There are four primary characters in this tale of twisted revenge: Michael; the titular Auggie, who is a shady grifter that Michael both admires and distrusts; Michael's love interest Melony; and Jonny, another grifter who, being older than the others, believes himself to be wiser, and therefore is the éminence grise of the trio (this group doesn't include Melony until later in the novel). All four of these characters take turns as narrators. Michael, or "Prof," is, like Cyrus Duffleman, overworked and underpaid, and even though, unlike the Duffer, has actually completed a 
$\mathrm{PhD}$, he is unlikely ever to get a permanent position in any school. However, he is too busy to confront his dead-end situation on a conscious level, and Jonny is the one to state that the Prof has been in a trap from which he and Auggie have released him. This is only between Jonny and the reader, because Jonny is narrating at the time. There is, of course, the possibility that Jonny is here being an unreliable, or at least self-serving, narrator, because the "Prof" winds up incarcerated for twenty years in a Federal prison: "a cot and three squares," as one of the grifters puts it.

I don't regret what may seem to be a "spoiler" above, because the novel starts in medias res with the Prof in prison; the vast majority of the novel is the recounting of how he landed there. What is significant is not that Vittinger has committed a crime, ostensibly to avenge the prolonged abuse that Auggie underwent as a child, but that his long process of formal education has led him to a barely life-sustaining job, and that, as an academic philosopher, he falls prey to the grandiose fantasies of certain Continental forbears. It is not by chance that the Prof at one point is reading Nietzsche's The Will to Power - although he admits he doesn't have a clear grasp of what those aphorisms mean - nor that he conceives of acts that are "Raskolnikovian" and then commits two murders with a sense of his own moral rectitude. Things are out of balance in a society that highly educates thinkers and then fails to provide them with positions for which they could earn a decent wage. In a larger sense, the Prof includes himself in "the ninety-nine per cent" of the Occupy movement who are living from paycheck to paycheck - if that - while members of "the one per cent" who own the vast majority of America's wealth rarely if ever deign to stoop so low as to see how the other $99 \%$ live.

Michael Vittinger, the "Prof" whose academic field is philosophy, embodies Diogenes the cynic because of his constant cynical observations of the inequities and injustices of the society he experiences on a personal level and reads about in newspapers and sees projected on television. At the same time, just as the "dog philosopher" lay in the streets like a dog, Vittinger shamelessly scours wastebaskets for discarded and partly eaten slices of pizza and hamburgers - although he registers disgust when he realizes that the burger turns out to be made from vegetables rather than meat. A later sequence in the novel sees the philosopher living as a homeless person, stealing vegetables from community garden plots, sleeping on the ground, and generally trying to hide from the law by 
entering the shady world at the margins of society.

There is much humor in this book, albeit the kind of bitter, cynical humor one might associate with a Voltaire or an Ambrose Bierce, but the style of the book has much more in common with the noir crime novels of Raymond Chandler. The counterpoint between the academic philosophies of Michel Foucault and Heidegger that Vittinger reads and teaches, on the one hand, and the "philosophies of life" that Auggie and Jonny espouse based on their education in the School of Hard Knocks, on the other, emphasizes the disparity between the Two Cultures of the Academy and the Real World that Auggie's Revenge forces together. TRIGGER WARNING: although the author himself does not use the kind of language that capitalizes on racial, ethnic, gender, or related slurs, his characters, being true to their real-world counterparts in West Philadelphia, Camden, New Jersey, and trailer courts in much of America, do use such language at times.

The liberal intellectual élite and its world-view, which has been so shockingly repudiated in the recent American elections, comes in for serious critique in this novel, even if it is in the form of random theorizing on the part of the Prof, Jonny, or Auggie. Auggie himself was sexually abused by his stepfather for years as a child, which has won him Michael's sympathy and fascinates Michael's girlfriend Melony - a source of predictable tension. However serious this may be, one is reminded of the line of a gang member in West Side Story - "Hey, I'm depraved on account of I'm deprived!" Kudera walks a delicate balance in this novel between a cynical condemnation of contemporary society, both liberals and conservatives among the well-off, and proffering some sense of a hope in the future. In this case, the hope lies in the fact that Michael Vittinger, adjunct professor of philosophy turned convict, has fifteen to twenty years to write his book, and the prison library that is available to him (he can take as many as three books back with him to his cell) apparently is well stocked. Who knows? maybe they'll have interlibrary loan...

DON RIGGS, Drexel University 